\title{
INNOVATION PROCESSES IN THE VOCATIONAL EDUCATION SYSTEM CONSULTING DEVELOPMENT
}

\author{
Sergei Y. Lavrentiev ${ }^{1 *}$, Dmitry A. Krylov ${ }^{2}$, Elena V. Kondratenko ${ }^{3}$ \\ ${ }^{1}$ Assoc. Prof., Faculty of General and Vocational Education, Mari State University, Russia, \\ lavrsu@mail.ru \\ ${ }^{2}$ Assoc. Prof., Faculty of General and Vocational Education, Mari State University, Russia, \\ krilda@mail.ru \\ ${ }^{3}$ Prof, Director of Pedagogical Institute, Mari State University, Russia, \\ elena kondratenko12@mail.ru \\ ${ }^{*}$ Corresponding Author
}

\begin{abstract}
The tendencies of innovative processes of post-industrial development of higher education are revealed and analyzed, the peculiarities of its functioning in the era of the economy based on knowledge are characterized. The social order of public organizations, employers initiated a new impetus for the emergence of needs in the provision of consulting assistance, pedagogical support of the educational process in the system of higher and secondary vocational education using innovative technologies. The essence of innovative pedagogical consulting lies in the provision of the necessary assistance by a competent specialist in identifying contradictions arising in the educational process and in a qualified solution of problems by an educational organization using modern technologies. The penetration of innovative technologies into all spheres of a person's life determines the level of requirements for a university graduate to master STEAM skills, self-realization in his chosen profession, as well as adaptation of technical projects to the changing socio-economic environment.
\end{abstract}

Keywords: Consulting, Innovations, STEAM consulting, Vocational education.

\section{INTRODUCTION}

The relevance of consulting research in Russian education is also determined by the fact that the activities of consultants are aimed at providing intellectual services in various types (organizational, psychological and pedagogical, training, managerial) professional activities of pedagogical and managerial personnel. Today, pedagogical consulting is becoming one of the university innovative development key vectors, increasing efficiency and, as a result, competitiveness in the provision of educational services.

The need to develop innovations in the theory and practice of pedagogical counseling is due to the ambivalence of modernizing the entire education system. Duality and ambiguity of the reforming processes characterize the globalization tendencies of the informational stage of an innovation-oriented knowledgebased economy development. The target directions of these processes are indicated in the key provisions of the concept of innovative development.

It should be noted that the widespread dissemination of innovative technologies will inevitably cause significant changes in the structure of employment, the competencies required from the workers and consultants themselves. Employers formulate new requirements for the employees' competencies and the speed of their formation. If in the XX century professions appeared once every 25-30 years, then in the XXI 
century, they appear every 3-5 years. Such traditionally well-known skills as: knowledge of a foreign language, the basics of market relations, law are significantly losing their positions. Today, at the merger of traditional spheres and innovative technologies, new professions, industries, and, therefore, competencies arise.

In the era of digital transformations that have affected all spheres of the post-industrial world, the relevance of providing consulting support to university students is of particular value. A distinctive of the society's progressive development feature is the growth trend of the services provided and professional consulting support, the share of which significantly exceeds the volume of industrial production (Lavrentiev, Krylov, 2017).

\section{DISCUSSION}

Most of the gross domestic product of the G20 countries (excluding India - 32\% and Indonesia - $49 \%$ ) is generated in the field of social, public services, education, medical consulting, as well as in companies specializing in legal, tax and financial consulting. The extensive geography of developed countries statistical reporting clearly indicates the excess of those employed share in the service sector over the total number of industrial and production personnel and agricultural producers. As of January 1, 2020, the share of people employed in the private and public sectors of the economy of Western Europe, the USA, and Japan ranged from $70 \%$ to $81 \%$.

According to the data graphically reflected in Figure 1, the largest employed share in the service sector among developed countries in the UK (81\%) is concentrated, and the smallest in Italy and Korea (70\%).

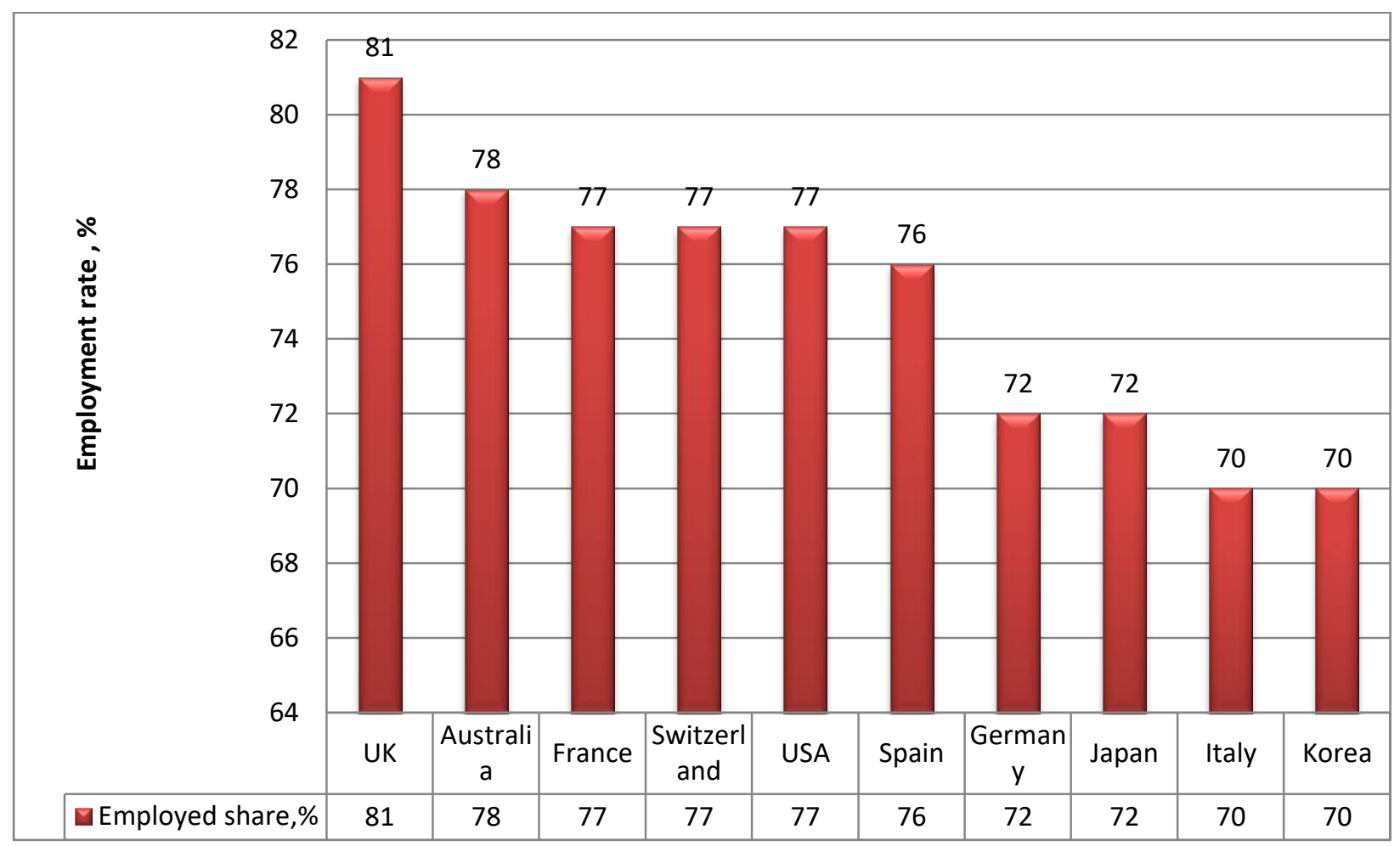

Figure 1. Share of employed in the service sector of developed countries

The service sector development, digital innovations, diversification of economic relations in various areas of society is increasingly associated with consulting activities. The "consulting" concept (from Latin "Consultatio") meaning "to confer", implies the competent specialist assistance in the vocational study and problematic situations subsequent solution arising in the organization. The consulting concept widespread in the scientific literature has become on economics, finance, works on management and in the practical activities of professional consulting centers that provide assistance in conducting educational trainings, legal support of transactions and psychological and pedagogical support. Consulting activities in international legal documents regulating professional activities from a single specialist to the procedure for the functioning of state institutions and public organizations can also be found.

The emergence and further development of the need for consulting services is observed at all levels of 
educational system. Innovative processes that determine the growth of the need for consulting activities distinguish it from the previous period of socio-economic development (Kalyuzhnova, Mrochkovsky, 2013).

The social responsibility is a kind of vector for the future professional training, significantly changing the ideas about the economy scientific and technological development goals and objectives. One of the important professional training components quality systems is the development of critical scientific thinking skills, the systematization of engineering creative innovations, the expansion of professional mobility is an STEAM consulting. The abbreviation of the term STEAM is formed from the merger of five academic disciplines first letters names: science, technology, engineering, art and mathematics (Lavrentiev, Krylov, 2018).

The innovative approaches of interdisciplinary STEAM counseling are manifested in the cognitive advantage of the future specialist, thereby providing a solid foundation for understanding the laws of the material and abstract world. The organic combination of engineering and art is embodied in complex architectural projects, landscape design, and industrial innovative solutions. To more effectively develop the professional competencies of students, professor of engineering at the University of South Florida David Snider has combined the study of electromagnetism with practice in the field of visual arts. The research tasks of STEAM consulting university students were to study the effect of light waves on the color perception of the surrounding space.

Humanizing engineering education with museology methods can serve as another example of STEAM consulting. Aerospace design innovation exhibits are being organized at the Institute of the Arts of the Chicago Department of Architecture in partnership with the National Aeronautics and Space Administration (NASA) Aerospace Technology Enterprise. The exhibition staff clearly demonstrated the results of innovative developments for aircraft with "morphing" wings, "skins" of self-generating vehicles, biological sensors designed to ensure safety, environmental friendliness and accessibility of flights for the population.

Mutual enrichment of STEAM technologies and various genres in the field of performing arts, in addition to scientific and technological training, develop the communicative competencies of students. Accompanying all stages of project activities with high dynamics of cooperation, the interactive component of joint performances contributes to the effective team building of novice innovators and experienced researchers. The high connection between art and STEAM consulting is confirmed by the results of a study conducted by Robert Root-Bernstein, during which the hypothesis that Nobel laureates are 22 times more likely than other researchers to be organizers and active participants in various kinds of events in the performing arts.

The techniques of musical art also serve as a successful embodiment in scientific research. To increase the investment attractiveness of the planned research, scientific groups initiate new approaches to their presentation. For example, in the Gene2Music research project, in order for the audience to "hear" the protein patterns, a group of scientists led by Miller assigned a combination of musical notes to each protein sequence encoded by the genome. And Victor Wong, a student of his master's program at Cornell University (New York, USA), has developed a special computer program that, playing on the piano, translates the colors of the weather map from red to blue into 88 separate musical notations (Takahashi, Miller, 2007).

The changing external environment of the university, due to the modernization context of the implementation of professional standards, a change in the legal status of educational organizations, the search for ways to build the most optimal trajectories for the personal and professional growth of future specialists led to a discussion about the importance of innovation, and the emergence of a need for professional consultants on the development of education in in general and the university in particular.

\section{RESULTS}

The first innovation process is associated with a knowledge model transition to the human resources intellectualization and skills development for independent mastery of competencies. The knowledge component remains one of the key tools that play an important role in the progressive economic of states and societies development. The duration of active life increase, including the working age of the population, the desire to master other competencies increases the need for professional mobility and flexibility in lifelong education. Economic activity, transforming modern society, human civilization becomes not only qualitatively new technological changes, transforms the post-industrial society into an innovative one. An innovative society becomes a consumer of consulting assistance in the extraction, processing, analysis, interpretation and broadcasting of information.

The second innovative direction the diversification of socio-economic, educational, economic activities, ways to satisfy consumer needs, deepening technological specialization, expanding the information and 
communication flows included in them can be attributed to. The pandemic has accelerated introducing innovative digital technologies, augmented and virtual reality, and cloud services into the educational process. Following the regime of self-isolation, the restrictions due to the spread of coronavirus infection initiated the transfer of all participants the educational activities, educational relations to the digital space. One of the essential factors of information consulting in the humanization of the professional activities of all subjects of educational relations is the formation of a high culture in the field of digital technologies.

The third innovation process occurs under the influence of economic factors based on the acceleration of educational, material, financial, human flows using remote information and consulting technologies. These trends are seen when using computer programs, at the design stage, and bringing software applications to the consumer market through logistically verified planning systems and order fulfillment on time. Automation of these processes significantly increases the intensity for its consumer of the competition.

The fourth innovative change is characterized by the need of a high culture development, which serves as a kind of translator of humanization, especially in the context of the growth of information transparency of business processes. Globalization has initiated a more active of consultants involvement for a more effective solution of issues related to the optimization of human, financial, informational and material resources usage.

The fifth innovative trend is formed on the need to separate the main and non-main activities of the educational organization, implemented through the practice of outsourcing. The essence of the term origin "outsourcing" - the use of an external resource means the transfer of some of the regular functions of an unusual organization of activities to another narrow-profile company with the required set of competencies in the required area (consulting services, innovative developments, marketing activities, advertising campaigns etc.). The educational organization, thus, will focus its efforts on teaching and educational, scientific, psychological, pedagogical, social and other types of work.

The sixth direction can be viewed through the prism that transforms the traditionally established areas of professional and entrepreneurial activity. Such innovative areas of professional activity that arise as a response to a consumer's request can be defined as information-intensive. In the professional activity of the consultant, a new entrepreneurial resource has emerged - competencies in identifying, analyzing and practical use of innovations. The socio-economic phenomenon of "big data", which allows analyzing huge massive data in problem areas, has been compared to the industrial revolution. The transnational, borderless phenomenon of the digital space, together with great opportunities for improving the quality of life of the population, improving the performance of all participants in the global market, inevitably entails threats of international cybercrime, hacker attacks, digital data fraud, etc.

\section{CONCLUSION}

The penetration of innovative technologies into all spheres of a person's life determines the level of requirements for a university graduate to master STEAM skills, self-realization in his chosen profession, as well as adaptation of technical projects to the changing socio-economic environment. Increasing the role of the human factor in the management of technically complex systems that improve the quality of life of the population determines the development of such educational programs that contribute to the preparation of a future specialist in the direction of technical and technological professionalism and the use of competencies in the field of organizing a safe environment and a strategic vision for the development of society.

Thus, the need to create conditions for sustainably stable socio-economic, cultural, production-technological, innovative development led to the expansion of the use of educational consulting in almost all areas of professional activity. The essence of innovative pedagogical consulting lies in the provision of the necessary assistance by a competent specialist in identifying contradictions arising in the educational process and in a qualified solution of problems by an educational organization using modern technologies.

\section{REFERENCE LIST}

Lavrentiev S.Y., Krylov D.A. The use of electronic technologies in the educational environment of the university // Modern science-intensive technologies. - 2017. - No. 11. - S. 129-133. URL: http://www.top-technologies.ru/ru/article/view?id=36857.

The share of those employed in the service sector. [Electronic resource]. - Access mode: https://www.economicdata.ru/economics.php?menu=macroeconomics\&data_type=economics\&data_ti 
cker=ServicesEmploy.

Kalyuzhnova N.Y., Mrochkovsky N.S. The role of consulting in the modern economy / N.Ya. Kalyuzhnova, N.S. Mrochkovsky // Bulletin of the Irkutsk State Technical University. 2013. No. 7 (78). S. 164-173. [Electronic resource]. - Access mode: https://elibrary.ru/download/elibrary_19959938_61576363.pdf.

Lavrentiev S.Y., Krylov D.A. Consulting innovative processes in the university: features and characteristics // Modern problems of science and education. - 2018. - No. 6. URL: http://www.scienceeducation.ru/ru/article/view?id=28426.

National Science Foundation (2006). The Art of Engineering. Professor uses the fine arts to broaden students' engineering perspectives. https://www.nsf.gov/news/news_summ.jsp?cntn_id=107990.

Aerospace Design (2014). The Art of Engineering from NASA's Aeronautical Research. https://archive.artic.edu/nasa/overview.html.

STEAM: Experts Make Case for Adding Arts to STEM. (2011). Education Week. Vol. 31, Issue 13, Page 8. https://www.edweek.org/ew/articles/2011/12/01/13steam_ep.h31.html.

Takahashi R, Miller J.H. Conversion of amino-acid sequence in proteins to classical music: search for auditory patterns. Genome Biol. 2007;8(5):405. doi: 10.1186/gb-2007-8-5-405. 